Article

\title{
Impact of Women and Independent Directors on Corporate Social Responsibility and Financial Performance: Empirical Evidence from an Emerging Economy
}

\author{
Chenxi Wang ${ }^{1, *}$, Xincai Deng ${ }^{2}$, Susana Álvarez-Otero ${ }^{3 \oplus}$, Muhammad Safdar Sial ${ }^{4}$, Ubaldo Comite ${ }^{5}$, \\ Jacob Cherian ${ }^{6}$ and Judit Oláh ${ }^{7}$ (i) \\ check for \\ updates \\ School of Management, Jinan University, Guangzhou 510632, China \\ 2 School of Economics and Management, Guizhou Normal University, Guizhou 550001, China; \\ dxc826@vip.sina.com \\ 3 Department of Business Administration, Faculty of Economics and Business, University of Oviedo, \\ 33003 Oviedo, Spain; saotero@uniovi.es \\ 4 Department of Management Sciences, COMSATS University Islamabad (CUI), Islamabad 44000, Pakistan; \\ safdarsial@comsats.edu.pk \\ 5 Department of Business Sciences, University Giustino Fortunato, 82100 Benevento, Italy; \\ u.comite@unifortunato.eu \\ 6 College of Business, Abu Dhabi University, Abu Dhabi P.O. Box 59911, United Arab Emirates; \\ jacob.cherian@adu.ac.ae \\ 7 Department of Management, Faculty of Applied Sciences, WSB University, 41-300 Dabrowa Górnicza, Poland \\ juditdrolah@gmail.com \\ * Correspondence: wangcx13@stu2018.jnu.edu.cn
}

Citation: Wang, C.; Deng, X.; Álvarez-Otero, S.; Sial, M.S.; Comite,

U.; Cherian, J.; Oláh, J. Impact of Women and Independent Directors on Corporate Social Responsibility and Financial Performance: Empirical Evidence from an Emerging Economy Sustainability 2021, 13, 6053. https:// doi.org/10.3390/su13116053

Academic Editors: Wen-Hsien Tsai and Cheng-Tsu Huang

Received: 26 April 2021

Accepted: 24 May 2021

Published: 27 May 2021

Publisher's Note: MDPI stays neutral with regard to jurisdictional claims in published maps and institutional affiliations.

Copyright: (C) 2021 by the authors Licensee MDPI, Basel, Switzerland This article is an open access article distributed under the terms and conditions of the Creative Commons Attribution (CC BY) license (https:// creativecommons.org/licenses/by/ $4.0 /)$.

\begin{abstract}
The purpose of our study is to investigate the impact of women and independent directors on corporate social responsibility and financial performance. We use the fixed effect regression model as a baseline methodology. The data set includes information from 2010 to 2019 regarding Chinese non-financial companies, from which we use yearly information. The RSK rating is used for the assessment of corporate social responsibility reporting, ranging from 0 to 100, and other data are taken from the China stock market and accounting research (CSMAR) database. We use a two-stage least square (TSLS) regression model to control the possible problem of endogeneity. The empirical results show that gender diversity in boards significantly and positively affects CSR reporting. We do not find an effect due to non-executive directors on CSR reporting. The presence of non-executive directors on a board is mostly trivial in the case of China, as they do not have much influence with regard to decision making, especially related to CSR reporting. The control variables, such as board size, board member meeting frequency and leverage, are also found to have a significant effect on CSR reporting. Therefore, our results add a new aspect to the emerging literature on CSR reporting, especially in China. Furthermore, our results are robust with regard to the alternative variables under consideration. Our study has important implications. Our research enriches the existing literature on CSR and highlights the importance of female and independent directors having an impact on decisions related to the increased reporting of CSR activities. Our study contributes to the existing literature by presenting a pioneering investigation of the effect of female and independent directors on CSR reporting, as well as shedding light on the relationship in the context of an emerging economy.
\end{abstract}

Keywords: female directors; independent directors; CSR reporting; corporate governance; China

\section{Introduction}

The main aim of this empirical study is to add to the available literature on CSR reporting by studying the effect of female and independent directors on company boards on CSR reporting by Chinese companies. More precisely, the research paper examines 
whether female and independent directors on boards influence the CSR reporting of Chinese firms.

The recent trends in valuation practices around the world include the evaluation of both financial and non-financial aspects, such as CSR disclosures. Thus, CSR activities and their disclosures have now become an integral part of company policies around the world. Thus, organizations are forced to consider CSR activities as part of their business strategies.

The rapid growth of the Chinese economy in the last few decades has shone a spotlight on the practices of CSR in China. According to Shin [1], with the advent of international investment and globalization, the Chinese corporate sector has rapidly adopted the international standards of CSR. One of the main pillars in this regard has been the inclusion of female directors and independent directors on company boards. The inclusion of women in such a role has been increasing with time. Two of the most important questions that we plan to explore mainly relate to the effectiveness and improvement of CSR reporting as the Chinese corporate sector continues to evolve with time: the first question mainly relates to improvements in social reporting with the improvement in the representation of female directors in the Chinese corporate sector [2] and whether the CSR scores of Chinese companies following this pattern have improved [3]; the second question mainly relates to the role of independent directors in improving overall CSR awareness within the Chinese corporate sector. Both questions are addressed using the RKS ratings for Chinese non-financial companies for the period of 2009 to 2019.

CSR has been the subject of academic debate for a long time, as it has been linked directly to the public interest. In the case of China, it is a legal requirement and can be summarized as follows: during business operation, a company has to abide by the local laws, regulations, follow the ethical and social considerations set out by law, observe moral principles and ethics and make decisions in good faith. The level to which a company abides by these regulations is dependent upon many factors. Bernardi and Bosco [4] state that one of the important factors is gender diversity amongst the directors of a company; Landry et al. (2016) also support this notion. Over time, gender diversity has become the norm rather than the exception, as increasing numbers of females are holding top-level offices; thus, it has also become the subject of various academic studies. This research aims to explore the impact of female and independent directors on the behavior of firms towards CSR reporting in the Chinese corporate context.

\section{Importance of Women and Independent Directors}

The board of directors is one of the most powerful entities within an organization, as it determines the direction of the organization's policies. These policies may be centered around the sole protection of shareholders' interests. Jiang and Kim [5] state that the board of directors is also responsible for the performance of the organization in terms of financial and social performance and is held accountable for decisions that affect the shareholders interests. The level of CSR activities and disclosure is also dependent upon the decisions of the board of directors. Personal wealth consideration mainly influences their decisions regarding social activities and their disclosure [6]. Jensen and Meckling [7] relate this to the separation of management and ownership; as the board of directors has the control, they are tempted to increase their wealth and power at the cost of shareholders. This also causes information asymmetry between the board and the shareholders. This leads to questions being raised by the public about the monitoring aspect of the board of directors. The independence of the board usually leads to failures of the monitoring aspect. According to Buniamin and Alrazi [8], such issues need to be analyzed by taking the internal working mechanism of the board into account, as only the shareholders and other stakeholders will be able to gain insights into the corporate decisions that directly impact them.

The role and responsibilities of the board of directors are to ensure not only the optimum utilization of available resources, but also to value creation by following the rules, regulations and corporate code of ethics [9]. Corporate scandals such as ENRON and WorldCom in the USA and One. Tel and HIH insurance in Australia have led to 
increasing security regarding the supervisory and oversight roles of boards of directors around the world.

The majority of previous studies have been centered around the economic aspect of gender diversity and has explored the impact of the inclusion of women on the board of directors on the financial performance of the firms [10]. The results are inconclusive, which to some extent weakens the case for gender diversity in the board of directors. Robinson and Dechant [11] have stressed that researchers need to treat it as a corporate initiative so that the organizations can in letter and spirit follow the policies set out by regulators regarding gender diversity. Meanwhile, Ferreira [12] has also criticized the economic aspect, as gender diversity is not solely responsible for financial performance, as many other factors play a vital role in this respect.

One of the main mechanisms for ensuring that the board of directors does not deviate from their stated objectives and does not pursue personal objectives at the cost of shareholders is the presence of independent directors in the board of directors (Khan et al., 2013). Their presence ensures that the supervisory function of the board is fulfilled [13] and decision-making is effective [14], and they ensure transparency in the functioning of the corporate system [15]. Their main function is to guarantee that the shareholders have been appropriately looked after in such a way that the organization follows the law and also protects the minority shareholding groups and other stakeholders [16]. According to de Oliveira, Espindola [13], their inclusion reduced the agency conflicts and costs associated with such conflicts. Since they are not employed by the organization they are better able to perform their supervisory duties, and they also tend toward good relationships with other stakeholders, so they are in a better position to understand their fears and expectations [17].

Meanwhile, Haniffa and Cooke [18] associate their presence with improvement in CSR activities as well. Khan [19] states that they are much more inclined to follow the norms and cultural practices of the general society with such knowledge, and they are better able to perform their duties independently and impartially [20], thus they improve the overall reputation of the organizations. The independent directors are usually more interested in improving not only the corporate setup, but also pay close attention to social activities and thus can improve the social image and behavior of the organization [21]. Rao and Tilt [15] link their presence on the board of directors with positive changes that are not only social, but also the environmental conduct of the organizations.

Our study contributes to the existing literature in many ways. First, the inclusion of women on the board of directors is a subject of debate not only in academic circles, but also in media and for policymakers, especially in the past few decades around the globe. It has been considered as one of the most important factors in changing corporate setups around the world, and [22] also links it to tackling the existence of friction amongst the general society and markets. Many European countries such as Germany and Norway have made mandatory quotas for women on the board of directors, while countries like the USA and UK mainly rely on voluntary actions by companies based upon gender equality principles in this regard. Campbell and Mínguez-Vera [23] also state that inclusion of women in the board is not only linked to ethics, but also has strong economic relations as well, and the majority of the studies are carried out in developed economies based in western countries. Their findings cannot be generalized and applied to economies of developing countries like China. The study on the female and independent directors in the Chinese market provides a unique opportunity to study their motivations and actions in the context of developing countries.

Second, the role played by the board of directors is of utmost importance as far as corporate decision-making is concerned, as they are responsible for formulating and finalizing the corporate strategies along with management of resources available to a corporate entity [24]. The role of independent directors becomes vital, as they hold similar powers as the board of directors and also occupy the key positions within the board's power structure to ensure that no corporate governance issue arises. This issue gained more importance with the advent of corporate scandals, which were caused mainly by corporate 
governance issues. With the appearance of such scandals, many campaigns organized by civil societies around the world gained momentum as they demanded transparent corporate governance systems and business practices in line with accepted norms of social responsibilities [25]. The focus of the past and present research seems to determine the factors influencing CSR activities. With exception of Peters and Romi [26], who discussed the importance of the position of Chief Sustainability Officer and also highlighted the importance of environmental committee most of the researchers have not focused their attention on the impact of actions of the board of directors on the activities of firms related to corporate social responsibility (CSR) reporting. Third, the present study contributes to the existing literature as this study focuses on China, and most of the related studies on the topic are conducted in the context of developed countries, so the studies in Asian or developing countries are very limited. Our study bridges the gap by focusing on Chinese corporate sectors, which are suffering from both environmental and social issues as most of the companies focused on the rapid growth, and social, along with environmental issues associated with such a high growth rate were largely ignored.

The results of the study show that female directors on the board have a significantly positive effect on CSR reporting. We do not find the effect of independent directors on CSR reporting. Our results are in line with the findings of [27], who had earlier concluded that the presence of independent directors in the board is mostly trivial in the case of China as they do not have much influence when it comes to decision making, especially related to CSR activities. Regarding control variables board size, board member meeting frequency, and leverage also have a significant effect on CSR reporting. Therefore, the present research study adds to the literature on CSR reporting by giving some empirical picture about the gender diversity and independent directors in the board, which is a very crucial corporate governance aspect and the extent of CSR reporting in the developing economies context, like China. More specifically, it is the very pioneer attempt that only targeting empirically and testing the influence of female and independent directors on CSR reporting.

The rest of the paper is organized as follows. Section 2 represents the theoretical framework, literature review, and hypotheses; Section 3 relates to research methodology; Section 4 describes empirical results and discussions, and the last part, Section 5, gives a conclusion with implications for further research in the future.

\section{Theoretical Background, Literature Review, and Hypothesis Development}

\subsection{Theoretical Background}

The corporate governance issues related to the governance of companies come under the framework of "agency theory", which surfaced in the 1970s. This theory tends to explain the underlying conflicts of interest that exist between owners of companies (shareholders also known as principals) and the people running the companies (managers also known as agents) and also describes the possible solution of such conflicts. This theory states that conflict arises when shareholders feel that they are losing control of their business while managers are increasing their control, thus with an increase in control they might increase their financial incentives at the expense of shareholders. Jensen and Meckling [7] describe this relationship as a contractual relationship under which one or more agents act on the best of owners or shareholders and make corporate decisions on their behalf. According to this theory, the main issue is caused when owners are not involved in running of the business, the control over business decisions cause the agency conflicts.

The main issue relates to the excessive risk-taking by agents once they get control of the company at the cost of owners or principals. Such activities usually relate to investments in ill-perceived and non-profitable projects, along with un-productive use of cashflows, see Fama and Jensen [16]. These conflicts are a common sight in developed western economies. While in the case of developing countries, the ownership is usually concentrated amongst a few people, another form of such conflict arises, known as "principal-principal agency conflicts" [28,29]. This mainly relates to conflict of interest with the groups of shareholders, 
in which the majority shareholders tend to exploit the minority shareholding group, with help of agents, as these are also mainly appointed by the majority shareholding group.

Even if the system of corporate governance favors the supremacy of the shareholders, the managers or agents tend to undertake activities leading to CSR on grounds of selfinterest, to enhance their reputation. The difference in perception in this regard usually results in conflict and agency issues. In the case of developing countries, the issue takes form contour, as in these countries, the main issue is the existence of the "principalprincipal agency conflicts", as the string affiliation of the managers with the controlling group of shareholders results in managers transferring the existing wealth to the majority shareholding group at the expense of minority shareholders, by enacting policies that favor them over minority shareholders. Chang and Chen [30] state that in the case of Malaysia, the managers refrain from spending on CSR activities, as this tends to increase the overall profitability of companies, and this increases the wealth of controlling shareholders, which usually are a close family group and are lauded and rewarded for their negative actions, despite the pressure put on them by regulators and minority shareholders. In a sense, they only watch out for the interest of majority shareholders.

The agency conflict also has a cost associated with all other corporate actions, and eliminating such conflicts leads to reducing such costs. This way includes improving gender diversity within the board, especially amongst the independent directors [16,31]. Female and independent directors tend to prove more impartial, and thus help in improving overall transparency in strategic decisions, not to mention improving the reputation of companies. One of the reasons sighted for such outcomes by Michelon and Parbonetti [32] relates to the sensitivity of female and independent directors for all stakeholders, including minority shareholders and non-shareholding stakeholders. According to Donnelly and Mulcahy [33], voluntary CSR-based disclosures tend to reduce the level of asymmetric information amongst the different stakeholders of the company, and female and independent directors tend to ensure this as they are better able to align the objectives of organizations with those of stakeholders. This not only reduces the agency costs, but also helps in attaining the basic objective wealth maximization for existing shareholders by improving the monitoring function $[29,31,34-37]$.

\subsection{Literature Review and Hypothesis Development}

\subsubsection{Female Directors and CSR Reporting}

On average, the female directors are involved in more diverse roles in organizational setups as compared to men as they work in both corporate and social organizations such as NGOs, while men tend to specialize in a narrow field of expertise [38]. They tend to be more inclined towards the social aspects such as CSR when compared to men [39]. Hillman and Keim [38] note that the paths of women leaders are usually more long and arduous as compared to their male colleagues, and this notion is also backed by [40-42]. The main limitations in this respect are mostly with the cultural norms and gender discrimination. Physical traits such as appearance and type dressing are also scrutinized when they appear for higher job positions. They usually face discrimination, as many roles are considered to be only for men, which leads them to develop more sympathy towards social considerations such as fair treatment, transparency of systems, and social activities, which benefits a wide range of stakeholders $[43,44]$ such type of actions also strengthens the CSR performance of the organizations in which they work. The presence of women in power positions such as the board of directors also allows them to be more objective towards the existing CSR activities of the organization and they tend to be more scrutinizing towards the general CSR activities, and thus they are better able to root out any negative CSR activities. Thus, the improvement in gender diversity may improve not only the level of CSR activities, but also improve the overall positive impact of such activities.

It is evident from the study of literature that the inclusion of women in the board improves the overall performance of the corporate setup in general, and thus it has become an integral part of a corporate mechanism. The increase in gender diversity greatly improves 
the social performance of the companies [45]. Gender diversity is also supported by Carter and D'Souza [46], as according to the majority of times, opposite genders do not tend to question the ethnic, social, and cultural backgrounds of each other, which might be raised against people of the same gender by coming from traditional backgrounds. They also prove that companies with gender-diverse boards tend to be more profitable and are better able to maximize the wealth of shareholders.

Previous studies such as Williams [47], followed by Galbreath and Shum [48], favor the presence of women on the board of directors, as their presence tends to have a positive impact on the level of social disclosures; [49] also endorses the findings of these studies. Hafsi and Turgut [50] also add that gender-diverse boards significantly improve the social performance of companies. Earlier, Boyd [51] linked it to the resource dependency theory, as people from diverse backgrounds improve the quality of decision making, as they tend to respond in a much better way to the environmental and social effects of their business activities. Moreover, they realize the consequences much earlier and in a better manner, thus their response is also more effective.

Gender diversity is considered one of the most important aspects of corporate governance, and related literature scholars have argued in favor of gender-diverse boards as it improves the overall human capital, which leads to improved understanding of complex corporate issues as compared to a homogenous board of directors [52]. In the Pakistani context, Ikram and Su [53] held that female entrepreneurs at all levels play a vital role in economic activities. Thus, one must consider gender diversity on boards. The number of women directors present on the board is used as a representation of not only gender diversity, but also diversity within the board [52]. The support for the notion that gender diversity on the board improves CSR disclosure is at best unsatisfactory. Daily and Dalton [54] held that the presence of women on the board might force directors to look into the expectations of stakeholders, and Zhang and Zhu [55] also support this and add that in such a scenario, the fulfillment of CSR activities and disclosure becomes more viable. In light of this brief review, our first hypothesis can be formulated as follows:

\section{Hypothesis 1 (H1). Female directors affect CSR reporting.}

\subsubsection{Independent Directors and CSR Reporting}

The research on the impact of the independence of the board on CSR around the world has yielded mixed results. The reason could be attributed to many moderating factors such as the structure of corporate setups, regimes of corporate governance, nature of the organization, and corporate and legal requirements of specific countries. Along with this, the cultural and social norms specific to the region also play a major role in determining such impacts. Along these, the choice of variables used by researchers also have a great impact on the results. To improve transparency and protect the shareholders interests along with those of other stakeholders, the concept of independent variables was introduced in western economies in the middle of the 1980s [56]. In the Asian context, this innovation was mainly adopted after the advent of the southeast Asian financial crises in the closing years of the 1990s and the start of the 2000s. With the passage of time and the evolution of these economies, it gained importance for researchers and regulators. However, people still differ over their usefulness, and their effectiveness is still questioned by many researchers via the results of their research studies. The idea of a board of directors comprising a majority of independent directors in the Asian context is still new as compared to developed western economies. Our study comes at a time when this topic has gained prominence, as independent directors have been proven to be a valuable control mechanism for effective corporate governance.

Leung and Snell [57] concluded the presence of constructive association amongst the voluntary CSR disclosure and independence of boards in Hong Kong-listed companies. Similar relations and conclusions were held by [58] when they analyzed a sample of 104 companies listed in Singapore. Cheng and Courtenay [58] document a positive relationship 
between board independence and voluntary disclosure for 104 Singapore companies. Cerbioni and Parbonetti [59] also back their finding as they conducted their research on biotechnology-based companies in Europe. Rao and Tilt [15] conducted similar research on Australian banks, followed by [60], who researched Malaysian banks, and all held the same conclusions in general. Later, Jizi and Salama [61] also found a positive relationship between the independence of the board and CSR-based voluntary disclosures. The studies of Barako and Brown [62,63], followed by those of Akhtaruddin and Hossain [64], and Chau and Gray [65], also reported similar findings.

On the other hand, Eng and Mak [66] negate this notion, as they found a negative relationship between the number of independent directors and voluntary CSR reporting in a sample of 158 Singapore-listed companies, followed by Gul and Leung [67] and Ahmad and Rashid [68], who endorsed their findings. Abdullah and Mohamed [69] state that independent directors prove to be a hindrance in such voluntary disclosures, as they can influence the decision of the board due to their numbers.

Many scholars have also pointed to the absence of any significant relationship between the independent directors and voluntary CSR disclosures, and these mainly include $[14,70,71]$. The main reason attributed by Michelon and Parbonetti [32] is the fact that the main reason for the presence of independent directors on the board is to ensure the protection of rights of all stakeholders and to reduce the agency issues and associated cost. Therefore, most of the time, the voluntary reporting mechanism might be overlooked as it is mostly considered as an indirect mechanism of monitoring. At the same time, one cannot ignore the fact that the majority of studies have pointed out the existence of some sort of relationship between the independence of the board and CSR reporting. However, the focus of these studies is developed economies and Asia-based studies are very limited. We aim to examine the impact of the effect of independent directors on the CSR reporting of listed companies in China.

Scholars such as Adams, Hermalin [72] have discussed the reasons for the presence of independent directors on the board. They state that their presence not only ensures the reduction and even elimination of agency conflicts, but also ensures the effective monitoring of corporate decision-making processes, thus their presence improves the overall quality of management within the organization. The solution to attendance issues has also been pointed out by [73]. Fama and Jensen [16] followed by Ho and Shun Wong endorse their presence, as it ensures the improvement in the quality of CSR disclosure. Such findings are also validated by those of [74]. De Villiers and Naiker [75] highlighted that the presence of independent directors improves the environmental performance of companies as these directors collectively increase the knowledge pool, and thus the monitoring and oversight function improves. To conclude, we can safely say that the presence of independent directors improves the CSR performance of the companies. Therefore, our second hypothesis can be formulated as follows:

Hypothesis 2 (H2). Independent directors affect CSR reporting.

\section{Research Methodology}

\subsection{Sample and Data}

Our study is based on the data of Chinese listed companies starting from 2010 to 2019. Our data consists of 6029 annual observations of the listed Chinese companies, for testing our earlier held research hypotheses. Our sample companies only include non-financial companies as the requirement for financial companies greatly differs, and regulations regarding them are much more stringent. The panel data was considered for our statistical analysis. The sources of our data are CSR rating by RKS, which are considered to be one of the most reliable databases in terms of CSR ranking for Chinese companies, and other data taken from the China stock market and accounting research (CSMAR) database, CSMAR provides comprehensive information on both financial and non-financial aspects of Chinese 
companies. At the same time, RKS concentrates on the CSR ranking based upon GRI 3.0 (Global Reporting Initiative) for Chinese listed companies, and their credibility can be assessed from the fact that most of the past researchers have relied upon data provided by them in terms of CSR ratings [76].

\subsection{Selection of the Model}

We used regression-based analysis to test our hypotheses and to establish the presence and magnitude of the relationship amongst the independent and dependent variables. The research model was tested by conducting a Hausman test, and the resulting $p$-value was held to be less than 0.001 , thus we adopted the fixed effect model to conduct further analysis.

\subsection{Measurement of Dependent and Independent Variable \\ 3.3.1. Measuring CSR Reporting}

We have used the RSK, CSR ranking information for purpose of this study, which ranges from 0 to 100, and since it has been validated as a legitimate tool by [76]. They conducted the reliability of the ranking by conducting a robustness check. The independent variables of the study include female directors and independent directors on the board.

\subsubsection{Measuring Female and Independent Directors}

We measure the female directors by using the Blau index (BI) by using this formula as $1-\sum_{i=1}^{n} P_{i}^{2}$ where $P_{i}$ is the percent of women and male on the board and $n$ is 2 describing the number of categories (women and male). The number of independent directors within the board is measured as a percentage of independent directors on the board. The data for these variables have been obtained from the CSMAR database.

\subsubsection{Measurement of Control Variables}

The previous studies show that board size, board member meeting frequency, leverage, big4, and SOE have influenced the extent of CSR reporting (e.g., [77-79]. According to previous studies [80-82], a large board can be more flexible and efficient than a large board, as it is associated with fewer bureaucratic problems. Thus, we predict a positive correlation between board size and CSR reporting. Board meetings are an important factor for directors to carry out their duties and monitoring functions on management (Conger et al., 1998). Therefore, it is suggested that directors who meet more frequently are more likely to perform their duties well. Thus, we are expecting a positive relationship between board member meetings and CSR reporting. We follow Larcker and Richardson [83] and measure board member meeting frequency by the total number of meetings conducted in one year.

\subsection{Model Estimation}

We tested the effect of female and independent directors on CSR reporting by using the below regression equations. By following Sial et al., 2018, we used the fixed effect regression model as a baseline methodology to estimate the below regression equation.

$$
\operatorname{CSRR} i t=\beta_{0}+\beta_{1} \text { Female } D_{i t}+\beta_{2} \text { Ind } D_{i t}+\sum_{i=1}^{n} \beta_{n} C V_{i t}+\varepsilon_{i t}
$$

In Equation (1), CSRR is the proxy to measure corporate social responsibility. Female $D$ represents the female director's diversity on the board. $\beta_{0}$ is the intercept of firm CSR reporting, Ind $\mathrm{D}$ represents the independent directors in the board. $\beta_{1}$ and $\beta_{2}$ are the coefficients of the independent variable, and $\sum_{i=1}^{n} \beta_{n} C V_{i t}$ represents all control variables related to CSR reporting. $\varepsilon_{i t}$ represents the standard error. For the descriptions of variables, see Table 1. 
Table 1. Descriptive statistics.

\begin{tabular}{cccc}
\hline Variable & Obs & Mean & Std,Dev \\
\hline CSRR & 6029 & 0.4534 & 1.471 \\
Female.D & 6029 & 0.164 & 0.478 \\
Ind.D & 6029 & 0.369 & 1.485 \\
BS & 6029 & 9.103 & 1.913 \\
BMMF & 6029 & 8.874 & 2.739 \\
Big4 & 6029 & 0.175 & 0.827 \\
SOE & 6029 & 0.597 & 0.327 \\
Lev & 6029 & 0.495 & 0.818 \\
\hline
\end{tabular}

Note: Dependent variable is CSR reporting (CSRR, measured by using the rating score of the RKS rating agency. We measure the female directors (Female.D, by using the proxy of Blau index (BI) by using this formula as $1-\sum_{i=1}^{n} P_{i}^{2}$ where $P_{i}$ is the percent of women and men on the board and $\mathrm{n}$ is 2 describing the number of categories women and men). Independent directors (Ind.D, measured as a percentage of independent directors on the board). Board size (BS, the total number of directors in the board), board member meeting frequency (BMMF measured by the total number of meeting in one year), big 4 (Big4, if the firm audited their reports from big4, then equal to one, otherwise equal to zero), state-owned enterprises (SOE, if the firm is government-controlled the equal to one, otherwise equal to zero), leverage (Lev, measured by total debt divided by total assets).

\section{Empirical Results}

\subsection{Descriptive Statistics}

Table 2 represents the descriptive statistics. The mean value of CSR reporting is 0.4534 with standard deviation descriptive statistics. The average value of female directors is 0.164 with a standard deviation of 0.478 . The mean value of independent directors is 0.369 with a standard deviation of 1.485. It means, on average, 36 percent of independent directors exist on the Chinese board. The average value of board size is 09.103 with a standard deviation of 1.913. It means, on average, 9 board members exist on the Chinese board. The mean value of board member meeting frequency and leverage are 8.874 9.8666 and 0.495, respectively. The descriptive statistics can be found in Table 1.

Table 2. Pearson correlation.

\begin{tabular}{|c|c|c|c|c|c|c|c|c|c|}
\hline Variables & CSRR & Female.D & Ind.D & BS & BMMF & Big4 & SOE & Lev & VIF \\
\hline CSRR & 1.000 & & & & & & & & \\
\hline Female.D & $0.0627^{* *}$ & 1.000 & & & & & & & 2.614 \\
\hline Ind.D & $0.0618^{* *}$ & $0.0549 * *$ & 1.000 & & & & & & 3.852 \\
\hline BS & $0.5282 * *$ & $0.1527 * *$ & $0.0255^{* *}$ & 1.000 & & & & & 1.466 \\
\hline BMMF & 0.5464 * & 0.0579 * & $0.6871^{* * *}$ & $0.5567 *$ & 1.000 & & & & 2.272 \\
\hline Big4 & $0.0857^{* *}$ & $0.0858^{* *}$ & $0.6482^{* * *}$ & $0.3445^{* *}$ & $0.6362 * *$ & 1.000 & & & 4.825 \\
\hline SOE & 0.0568 & $0.5797^{* * *}$ & $0.0438^{* *}$ & 0.5678 & $0.0372 * *$ & 0.0363 & 1.000 & & 2.726 \\
\hline Lev & $0.0468^{* *}$ & 0.5747 * & $0.0467 *$ & $0.4345 *$ & $0.2839 * *$ & $0.7372 * * *$ & 0.3838 * & 1.000 & 2.654 \\
\hline
\end{tabular}

Note: Dependent variable is CSR reporting (CSRR, measured by using the rating score of the RKS rating agency. We measure the female directors (Female.D, by using the proxy of Blau index (BI) by using this formula as $1-\sum_{i=1}^{n} P_{i}^{2}$ where $P_{i}$ is the percent of women and men on the board and $\mathrm{n}$ is 2 describing the number of categories women and men). Independent directors (Ind.D, measured as the percentage of independent directors on the board. Board size (BS, the total number of directors in the board), board member meeting frequency (BMMF, measured by the total number of meeting in one year), big 4 (Big4, if firm audited their reports from big4 then equal to one, otherwise equal to zero), state-owned enterprises ( $\mathrm{SOE}$, if the firm is government-controlled the equal to one, otherwise equal to zero), leverage (Lev, measured by total debt divided by total assets), ${ }^{* * *},{ }^{* *}, *$ represent $p<0.01, p<0.05, p<0.1$.

\subsection{Correlation Matrix}

Table 2 shows the correlation matrix. The correlation coefficients of all variables are less than 0.80 . Therefore, there are no multicollinearity problems. The variance inflation factor (VIF) is also less than the thumb of the role of 10, which lessens multicollinearity concerns.

\subsection{Multivariate Analysis}

Table 3 represents the results. Model 1 shows the regression results of female directors on CSR reporting, suggests that female directors in the board (Blau Index) in model 1 $(\beta=1.864, p<0.05)$ are positively related to CSR reporting. Thus, our first hypothesis 
is accepted that female directors have a positive effect on CSR reporting. Moreover, the results are also totally aligned with $[15,84]$, who found the same relationship between female directors and CSR reporting. It also supports agency theory.

Table 3. Impact of female and independent directors on CSR reporting and financial performance.

\begin{tabular}{|c|c|c|c|c|c|c|c|c|}
\hline \multirow{2}{*}{ Variables } & \multicolumn{2}{|c|}{ Model 1 (CSRR) } & \multicolumn{2}{|c|}{ Model 2 (CSRR) } & \multicolumn{2}{|c|}{ Model 3 (ROA) } & \multicolumn{2}{|c|}{ Model 4 (ROA) } \\
\hline & Coef. & $p$-Value & Coef & $p$-Value & $p$-Value & Coef & $p$-Value & Coef \\
\hline Female.D (BI) & $1.864^{* *}$ & 0.045 & 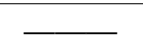 & $\longrightarrow$ & $1.324^{* *}$ & 0.021 & - & \\
\hline Ind.D & & & 1.322 & 0.213 & & & 1.432 & 0.235 \\
\hline BS & $0.065^{* * *}$ & 0.001 & $0.067^{* * *}$ & 0.007 & $0.052^{* * *}$ & 0.002 & $0.062^{* * *}$ & 0.005 \\
\hline BMMF & $0.063^{* * *}$ & 0.000 & $0.059^{* * *}$ & 0.000 & $0.034^{* * *}$ & 0.000 & $0.043^{* * *}$ & 0.000 \\
\hline Big4 & 0.076 & 0.687 & 0.087 & 0.902 & 0.063 & 0.687 & 0.082 & 0.902 \\
\hline SOE & 0.047 & 0.431 & 0.048 & 0.423 & 0.038 & 0.431 & 0.043 & 0.423 \\
\hline Lev & $-0.432 * *$ & 0.046 & $-0.145^{* *}$ & 0.049 & $-0.324 * *$ & 0.046 & $-0.134^{* *}$ & 0.049 \\
\hline YEAR & \multicolumn{2}{|c|}{ YES } & \multicolumn{2}{|c|}{ YES } & \multicolumn{2}{|c|}{ YES } & \multicolumn{2}{|c|}{ YES } \\
\hline INDUSTRY & \multicolumn{2}{|c|}{ YES } & \multicolumn{2}{|c|}{ YES } & \multicolumn{2}{|c|}{ YES } & \multicolumn{2}{|c|}{ YES } \\
\hline No of Obs & \multicolumn{2}{|c|}{6029} & \multicolumn{2}{|c|}{6029} & \multicolumn{2}{|c|}{6029} & \multicolumn{2}{|c|}{6029} \\
\hline $\mathrm{R}^{2}$ & \multicolumn{2}{|c|}{27.74} & \multicolumn{2}{|c|}{28.57} & \multicolumn{2}{|c|}{24.47} & \multicolumn{2}{|c|}{25.65} \\
\hline
\end{tabular}

Note: Dependent variable is CSR reporting (CSRR, measured by using the rating score of the RKS rating agency. We measure the female directors (Female.D, by using the proxy of Blau index (BI) by using this formula as $1-\sum_{i=1}^{n} P_{i}^{2}$ where $P_{i}$ is the percent of women and men on the board and $\mathrm{n}$ is 2 describing the number of categories women and men). Independent directors (Ind.D, measured as the percentage of independent directors on the board. Board size (BS, the total number of directors in the board), Board member meeting frequency (BMMF, measured by the total number of meeting in one year), Big 4 (Big4, if the firm audited their reports from big4 then equal to one, otherwise equal to zero), State-owned enterprises (SOE, if the firm is government-controlled the equal to one, otherwise equal to zero), Leverage (Lev, measured by total debt divided by total assets), ${ }^{* * *}, * *$, represents $p<0.01, p<0.05$.

Model 2 shows the regression results of independent directors on CSR reporting, suggesting that independent directors had no significant impact on the decision regarding CSR reporting by firms, as the results indicated that the role of these independent directors had insignificant $p$-values of 0.213 . This supports the findings of [85], which applies that they have trivial roles and powers when it comes to decision making. Therefore, we reject $\mathrm{H} 2$ based on the results. Our results (model 3) present that there is a positive relationship between women directors and financial performance $\left(\beta_{1}=01.324, p\right.$-value $\left.=0.021\right)$. Our results in (model 4 ) show the insignificant relationship between independent directors and financial performance.

The Chinese corporate culture is not well suited for non-executive directorship, as most of such directors occupy multiple positions, as in 2009 , almost $75 \%$ of the nonexecutive directors of the supervisory board were occupying multiple directorships. Such a high percentage is itself unique, and [86] researched the given data to assess whether they were able to execute their responsibilities. As it is commonly associated with reputation, a person with a high reputation is perceived to be a professional of the highest caliber, and thus would also have multiple supervisory directorships. This is the case in China, where the multiple directorships are favored by the corporate job market [87].

Regarding control variables, results show that the board's size and board member meeting frequency have a direct and significant relationship ( $p$ value $=0.001$ and $p$-value $=0.000$ ) with CSR reporting. It also clearly indicates that larger boards and more meetings of board members have more probability of providing higher CSR disclosures than smaller boards. This is consistent with the results found by other prior studies like $[61,70,88,89]$. We found a negative relationship between leverage and CSR reporting [90,91], because firms with high leverage always focus on short-term goals, instead of the long-term social goals of the corporation. Big4 and state-owned enterprises do not have any significant effect on CSR reporting.

\subsection{Discussion of Results}

The present study tends to explain the impact of female directors on CSR reporting. Our findings can be considered important since they tend to lend support to the positive 
impact of female directors on the level of CSR reporting. As it is commonly held that female directors, in general, tend to improve the level of CSR reporting. Our contribution mainly relates to testing of earlier held research hypotheses on a large data set and hold great importance for policymakers, practitioners, and top-level executives of companies and provides an in-depth understanding of the inclusion of females on the board as well as independent directors to improve the level of CSR reporting. Our study provides an opportunity for future researchers by explaining the impact of female directors on CSR reporting. Meanwhile, it will help the top-level executives to formulate the necessary policies for the improvement of gender diversity and CSR reporting mechanism, which in turn will be reflected in their valuation and improvement of the overall performance of their companies. Second, one of the main issues related to independent directors is the absence of financial benefits as compared to the other members of the board. They are elected by the board of directors, and most of them are serving as directors in other companies as well, even though they have in-depth knowledge of the mechanism, but due to lack of benefits and existing job responsibilities, they are mostly unable to execute the supervisory role. They usually rely on the information provided by the board of directors for their decision making, thus their effectiveness is mostly compromised.

In many cases, independent directors may lack the detailed knowledge of the company as well, but this can be improved if they regularly attend the board meetings, so they can familiarize themselves with the affairs of the company. If independent directors regularly attend the meetings, they are in a better position to analyze the information provided to them, and this can improve their decision-making. Another main issue related to the appointment of independent directors pointed out by Sartawi and Hindawi [71] is the selection based upon personal or family connections with the board of directors. Such issues greatly compromise the effectiveness of the supervisory role of their decisions. One of the major issues in China relates to state ownership of the majority of the corporations. The state ownership applies that the majority of the independent directors are appointed by the state based upon their political and personal connections and loyalty towards the political ideology. This, coupled with earlier identified problems, severely hinders the independent role, which independent directors are supposed to perform, leading to principal-principal agency issues within the state-owned and operated organization. Such problems can only be eliminated by the effectiveness of independent directors. Even though all these issues are present in the Chinese context, still no one can deny the importance of independent directors on the board. The results of current research partially lend support to agency theory, but also support the gender diversity within the board and independent directors and how this impacts the level of CSR reporting.

\subsection{Robustness Tests}

\subsubsection{An Alternative Measure of Boardroom Gender Diversity}

Table 4 shows the alternative measures of female directors for the robustness of our findings. We used two alternative measures of female directors, the number of proportions of female directors (PFD) and Shannon index. Coefficients of the PFD and Shannon index remain significantly positive at a 5 percent level $(\beta=1.735, p<0.05, \beta=2.544, p<0.05)$. These results confirm our main findings in Table 3.

\subsubsection{Problem of Endogeneity}

To resolve the problem of endogeneity by following previous studies [36], we used two-stage least square (TSLS) regression. Table 5 model 1 represents the result of the female director proxy (Blau index) on CSR reporting. The coefficient of the Blau index remains positive and significant at a 5 percent level $(\beta=1.767, p<0.05)$ and the coefficient of independent directors remains insignificant at 5 percent level $(\beta=1.752, p>0.05)$ The results of the two-stage least square model validate our main findings. 
Table 4. Robustness tests: Alternative measures of female directors.

\begin{tabular}{|c|c|c|c|c|}
\hline \multirow{2}{*}{ Variables } & \multicolumn{2}{|c|}{ Model 1 (CSRR) } & \multicolumn{2}{|c|}{ Model 2 (CSRR) } \\
\hline & Coef. & $p$-Value & Coef & $p$-Value \\
\hline Female.D (PFD) & $1.735^{* *}$ & 0.012 & - & - \\
\hline Female.D (Shannon.I) & - & $\longrightarrow$ & $2.544^{* *}$ & 0.0434 \\
\hline Ind.D & 1.357 & 0.112 & 1.726 & 0.146 \\
\hline BS & $0.076^{* *}$ & 0.030 & $0.079 * *$ & 0.056 \\
\hline BMMF & $0.075^{* * *}$ & 0.000 & $0.065^{* * *}$ & 0.000 \\
\hline Big4 & 0.087 & 0.575 & 0.090 & 0.129 \\
\hline SOE & 0.079 & 0.521 & 0.068 & 0.496 \\
\hline Lev & $-0.460^{* *}$ & 0.038 & $-0.075^{* *}$ & 0.049 \\
\hline YEAR & \multicolumn{2}{|c|}{ YES } & \multicolumn{2}{|c|}{ YES } \\
\hline INDUSTRY & \multicolumn{2}{|c|}{ YES } & \multicolumn{2}{|c|}{ YES } \\
\hline No of Obs & \multicolumn{2}{|c|}{6029} & \multicolumn{2}{|c|}{6029} \\
\hline $\mathrm{R}^{2}$ & \multicolumn{2}{|c|}{24.72} & \multicolumn{2}{|c|}{25.50} \\
\hline
\end{tabular}

Note: Dependent variable is CSR reporting (CSRR, measured by using the rating score of the RKS rating agency. We measure the female directors by taking the proportion of female directors on the board. The second proxy used to measure the female directors is the Shannon index (1948), it is represented by the equation $-\sum_{i=1}^{n} P_{i} \ln P_{i}$ in this $P_{i}$ represents the composition of the board of directors based upon gender and $\mathrm{n}$ is 2 indicating classifications of male \& female. Independent directors (Ind.D, measured as the percentage of independent directors on the board. Board size (BS, the total number of directors in the board), board member meeting frequency (BMMF, measured by the total number of meeting in one year), big 4 (Big4, if the firm audited their reports from big4 then equal to one, otherwise equal to zero), state-owned enterprises ( $\mathrm{SOE}$, if the firm is government-controlled the equal to one, otherwise equal to zero), leverage (Lev, measured by total debt divided by total assets), ${ }^{* * *}, * *$, represents $p<0.01, p<0.05$.

Table 5. Robustness tests: Problem of endogeneity.

\begin{tabular}{|c|c|c|c|c|}
\hline \multirow{2}{*}{ Variables } & \multicolumn{2}{|c|}{ Model 1 (CSRR) } & \multicolumn{2}{|c|}{ Model 2 (CSRR) } \\
\hline & Coef. & $p$-Value & Coef & $p$-Value \\
\hline Female.D (BI) & $1.767 * *$ & 0.019 & - & - \\
\hline Ind.D & - & - & 1.752 & 0.163 \\
\hline BS & $0.078^{* *}$ & 0.051 & $0.068^{* *}$ & 0.021 \\
\hline BMMF & $0.034^{* * *}$ & 0.001 & $0.067^{* * *}$ & 0.006 \\
\hline Big4 & 0.075 & 0.171 & 0.060 & 0.863 \\
\hline SOE & 0.080 & 0.523 & 0.054 & 0.312 \\
\hline Lev & $-0.417^{* *}$ & 0.013 & $-0.406^{* *}$ & 0.048 \\
\hline No of Obs & 6029 & 6029 & 6029 & 6029 \\
\hline WaldCh$^{2}$ & \multicolumn{2}{|c|}{957.91} & \multicolumn{2}{|c|}{808.20} \\
\hline $\mathrm{R}^{2}$ & \multicolumn{2}{|c|}{26.70} & \multicolumn{2}{|c|}{27.47} \\
\hline
\end{tabular}

Note: Dependent variable is CSR reporting (CSRR, measured by using the rating score of the RKS rating agency. We measure the female directors (Female.D, by using the proxy of Blau index (BI) by using this formula as $1-\sum_{i=1}^{n} P_{i}^{2}$ where $P_{i}$ is the percent of women and men on the board and $\mathrm{n}$ is 2 describing the number of categories women and men). Independent directors (Ind.D, measured as the percentage of independent directors on the board. Board size (BS, the total number of directors in the board), board member meeting frequency (BMMF, measured by the total number of meeting in one year), big 4 (Big4, if the firm audited their reports from big4 then equal to one, otherwise equal to zero), state-owned enterprises (SOE, if the firm is government-controlled the equal to one, otherwise equal to zero), leverage (Lev, measured by total debt divided by total assets), ***,**, represents $p<0.01, p<0.05$.

\section{Conclusions and Future Research}

The purpose of our study is to examine the impact of female and independent directors on the CSR reporting within the non-financial Chinese listed companies. The period of the study ranged from 2010 to 2019. As per our results, female directors significantly affect CSR reporting, but we did not find any significant relationship between independent directors with CSR reporting.

In short, female directors on boards can help to enhance organization reporting related to CSR. The findings of this have a look at the result in numerous useful summaries. First of all, listed organizations, the growing diversity of gender may improve the level of organizations CSR reporting. As already mentioned in the discussion above, this can be due 
to the various factors, which encompass better information of CSR at the organizational level and personal attributes of female directors. The existing studies provide beneficial insight for policymakers and regulators alike concerning how they can improve the effectiveness of the female directors and independent directors in terms of CSR reporting. The establishment of CSR-based ranking and its use as part of the valuation mechanism for companies can prompt independent directors and female directors to fulfill their roles more effectively. Our results also support the notion that improvement in the level of CSR reporting also holds reputational incentives for female and independent directors within the Chinese corporate sector. The results of our study are valuable contributions to the existing literature on general topics of CSR and females with independent directors.

\section{Practical Implications and Limitations}

To summarize, our study is useful for practitioners, educationists and managers of companies, as it helps in explaining the potential impacts of female directors within the board and the role of independent directors in improving the overall performance of the companies via improving the CSR performance of the companies. The results of our study are indicative of the importance of the inclusion of women in leading roles and will also serve to provide a legitimate base for their hiring at top levels of companies, as it helps to improve the performance of companies via improvement in CSR related disclosures.

Our study has some limitations. First, our study relates to only included Chinese listed companies and due to differences in the legislation, corporate culture, and social norms, the findings might not apply to other countries or regions. Future researchers can conduct cross-sectional studies to generalize the findings using a similar set of variables. Second, future researchers can add other variables with different aspects of organizational behavior, behavioral aspects of management at individual organizations and industrial levels. Third, they can also conduct cross-sectional studies using regional economies with similar socio-economic setups. The room for research in CSR-related areas is great specially in developing economies. In the Chinese context, researchers can explore the impact of behavioral aspects of the board of directors on CSR reporting.

Author Contributions: Conceptualization, C.W. and X.D.; formal analysis, S.Á.-O., U.C. and J.O.; investigation, M.S.S. and J.C.; methodology, S.Á.-O. and U.C.; resources, J.O.; supervision, M.S.S. and J.C.; writing-original draft, C.W. and X.D.; writing—review and editing, M.S.S., J.C. and J.O. All authors have read and agreed to the published version of the manuscript.

Funding: The project was funded under the program of the Minister of Science and Higher Education titled "Regional Initiative of Excellence" in 2019-2022, project number 018/RID/2018/19, the amount of funding PLN 10788 423,16.

Institutional Review Board Statement: Not applicable.

Informed Consent Statement: Informed consent was obtained from the respondents of the survey.

Data Availability Statement: The data will be made available on request from the corresponding author.

Conflicts of Interest: The authors declare no conflict of interest.

\section{References}

1. Shin, K.-Y. Corporate Social Responsibility. In Corporate Social Responsibility Reporting in China; Springer: Berlin/Heidelberg, Germany, 2014; pp. 1-21.

2. Lam, K.C.; McGuinness, P.B.; Vieito, J.P. CEO gender, executive compensation and firm performance in Chinese-listed enterprises. Pac. Basin Financ. J. 2013, 21, 1136-1159. [CrossRef]

3. Farag, H.; Mallin, C. The impact of the dual board structure and board diversity: Evidence from Chinese Initial Public Offerings (IPOs). J. Bus. Ethics 2016, 139, 333-349. [CrossRef]

4. Bernardi, R.A.; Bosco, S.M.; Columb, V.L. Does female representation on boards of directors associate with the 'most ethical companies' list? Corp. Reput. Rev. 2009, 12, 270-280. [CrossRef]

5. Jiang, F.; Kim, K.A. Corporate Governance in China: A modern Perspective; Elsevier: Amsterdam, The Netherlands, 2015.

6. Watts, R.L.; Zimmerman, J.L. Towards a positive theory of the determination of accounting standards. Account. Rev. 1978, 53, 112-134. 
7. Jensen, M.C.; Meckling, W.H. Theory of the firm: Managerial behavior, agency costs and ownership structure. J. Financ. Econ. 1976, 3, 305-360. [CrossRef]

8. Buniamin, S.; Alrazi, B.; Johari, N.H.; Rahman, N.R.A. Corporate governance practices and environmental reporting of companies in Malaysia: Finding possibilities of double thumbs up. J. Pengur. 2011, 32, 55-71.

9. Kemp, S. Corporate governance and corporate social responsibility: Lessons from the land of OZ. J. Manag. Gov. 2011, 15, 539-556. [CrossRef]

10. Post, C.; Byron, K. Women on boards and firm financial performance: A meta-analysis. Acad. Manag. J. 2015, 58, 1546-1571. [CrossRef]

11. Robinson, G.; Dechant, K. Building a business case for diversity. Acad. Manag. Perspect. 1997, 11, 21-31. [CrossRef]

12. Ferreira, D. Board diversity: Should we trust research to inform policy? Corp. Gov. Int. Rev. 2015, 23, 108-111. [CrossRef]

13. De Oliveira, U.R.; Espindola, L.S.; da Silva, I.R.; da Silva, I.N.; Rocha, H.M. A systematic literature review on green supply chain management: Research implications and future perspectives. J. Clean. Prod. 2018, 187, 537-561. [CrossRef]

14. Said, R.; Zainuddin, Y.H.; Haron, H. The relationship between corporate social responsibility disclosure and corporate governance characteristics in Malaysian public listed companies. Soc. Responsib. J. 2009, 5, 212-226. [CrossRef]

15. Rao, K.; Tilt, C. Board composition and corporate social responsibility: The role of diversity, gender, strategy and decision making. J. Bus. Ethics 2016, 138, 327-347. [CrossRef]

16. Fama, E.F.; Jensen, M.C. Separation of ownership and control. J. Law Econ. 1983, 26, 301-325. [CrossRef]

17. Ibrahim, N.A.; Angelidis, J.P. The corporate social responsiveness orientation of board members: Are there differences between inside and outside directors? J. Bus. Ethics 1995, 14, 405-410. [CrossRef]

18. Haniffa, R.M.; Cooke, T.E. The impact of culture and governance on corporate social reporting. J. Account. Public Policy 2005, 24, 391-430. [CrossRef]

19. Khan, H.-U.-Z. The effect of corporate governance elements on corporate social responsibility (CSR) reporting: Empirical evidence from private commercial banks of Bangladesh. Int. J. Law Manag. 2010, 52, 82-109. [CrossRef]

20. Fernández-Gago, R.; Cabeza-García, L.; Nieto, M. Corporate social responsibility, board of directors, and firm performance: An analysis of their relationships. Rev. Manag. Sci. 2016, 10, 85-104. [CrossRef]

21. Zahra, S.A.; Stanton, W.W. The implications of board of directors composition for corporate strategy and performance. Int. J. Manag. 1988, 5, 229-236.

22. Jaiswall, S.S.K.; Bhattacharyya, A.K. Corporate governance and CEO compensation in Indian firms. J. Contemp. Account. Econ. 2016, 12, 159-175. [CrossRef]

23. Campbell, K.; Mínguez-Vera, A. Gender diversity in the boardroom and firm financial performance. J. Bus. Ethics 2008, 83, 435-451. [CrossRef]

24. Nekhili, M.; Gatfaoui, H. Are demographic attributes and firm characteristics drivers of gender diversity? Investigating women's positions on French boards of directors. J. Bus. Ethics 2013, 118, 227-249. [CrossRef]

25. Lau, C.; Lu, Y.; Liang, Q. Corporate social responsibility in China: A corporate governance approach. J. Bus. Ethics 2016, 136, 73-87. [CrossRef]

26. Peters, G.F.; Romi, A.M. The association between sustainability governance characteristics and the assurance of corporate sustainability reports. Audit. J. Pract. Theory 2014, 34, 163-198. [CrossRef]

27. Sun, J.; Liu, G.; Lan, G. Does female directorship on independent audit committees constrain earnings management? J. Bus. Ethics 2011, 99, 369-382. [CrossRef]

28. Dharwadkar, B.; George, G.; Brandes, P. Privatization in emerging economies: An agency theory perspective. Acad. Manag. Rev. 2000, 25, 650-669. [CrossRef]

29. Ma, R.; Cherian, J.; Tsai, W.-H.; Sial, M.; Hou, L.; Álvarez-Otero, S. The Relationship of Corporate Social Responsibility on Digital Platforms, Electronic Word-of-Mouth, and Consumer-Company Identification: An Application of Social Identity Theory. Sustainability 2021, 13, 4700. [CrossRef]

30. Chang, D.-S.; Chen, S.-H.; Hsu, C.-W.; Hu, A.H. Identifying strategic factors of the implantation CSR in the airline industry: The case of Asia-Pacific airlines. Sustainability 2015, 7, 7762-7783. [CrossRef]

31. Kong, L.; Sial, M.; Ahmad, N.; Sehleanu, M.; Li, Z.; Zia-Ud-Din, M.; Badulescu, D. CSR as a potential motivator to shape employees' view towards nature for a sustainable workplace environment. Sustainability 2021, 13, 1499. [CrossRef]

32. Michelon, G.; Parbonetti, A. The effect of corporate governance on sustainability disclosure. J. Manag. Gov. 2012, 16, 477-509. [CrossRef]

33. Donnelly, R.; Mulcahy, M. Board structure, ownership, and voluntary disclosure in Ireland. Corp. Gov. Int. Rev. 2008, 16, 416-429. [CrossRef]

34. Sun, H.; Rabbani, M.; Ahmad, N.; Sial, M.; Guping, C.; Zia-Ud-Din, M.; Fu, Q. CSR, Co-Creation and Green Consumer Loyalty: Are Green Banking Initiatives Important? A Moderated Mediation Approach from an Emerging Economy. Sustainability 2020, 12, 10688. [CrossRef]

35. Chen, X.; Sial, M.S.; Tran, D.K.; Alhaddad, W.; Hwang, J.; Thu, P.A. Are Socially Responsible Companies Really Ethical? The Moderating Role of State-Owned Enterprises: Evidence from China. Sustainability 2020, 12, 2858. [CrossRef]

36. Sial, M.S.; Chunmei, Z.; Khan, T.; Nguyen, V.K. Corporate social responsibility, firm performance and the moderating effect of earnings management in Chinese firms. Asia Pac. J. Bus. Adm. 2018, 10, 184-199. [CrossRef] 
37. Sial, M.S.; Chunmei, Z.; Khuong, N.V. Do female and independent directors explain the two-way relationship between corporate social responsibility and earnings management of Chinese listed firms? Int. J. Account. Inf. Manag. 2019, 27, 442-460. [CrossRef]

38. Hillman, A.J.; Keim, G.D. Shareholder value, stakeholder management, and social issues: What's the bottom line? Strateg. Manag. J. 2001, 22, 125-139. [CrossRef]

39. Singh, M.P.; Chakraborty, A.; Roy, M. Entrepreneurial commitment, organizational sustainability and business performance of manufacturing MSMEs: Evidence from India. Int. J. Appl. Bus. Econ. Res. 2016, 14, 4615-4631.

40. Eagly, A.H.; Johnson, B.T. Gender and leadership style: A meta-analysis. Psychol. Bull. 1990, 108, 233. [CrossRef]

41. Sial, M.S.; Zheng, C.; Cherian, J.; Gulzar, M.; Thu, P.A.; Khan, T.; Khuong, N.V. Does Corporate Social Responsibility Mediate the Relation between Boardroom Gender Diversity and Firm Performance of Chinese Listed Companies? Sustainability 2018, 10, 3591. [CrossRef]

42. Sial, M.S.; Zheng, C.; Khuong, N.V.; Khan, T.; Usman, M. Does Firm Performance Influence Corporate Social Responsibility Reporting of Chinese Listed Companies? Sustainability 2018, 10, 2217. [CrossRef]

43. Kramer, V.W.; Konrad, A.M.; Erkut, S. Critical Mass on Corporate Boards: Why Three or more Women Enhance Governance; Wellesley Centers for Women: Wellesley, MA, USA, 2006.

44. Cook, A.; Glass, C. Women on corporate boards: Do they advance corporate social responsibility? Hum. Relat. 2018, 71, 897-924. [CrossRef]

45. Siciliano, J.I. The relationship of board member diversity to organizational performance. J. Bus. Ethics 1996, 15, 1313-1320. [CrossRef]

46. Carter, D.A.; D'Souza, F.; Simkins, B.J.; Simpson, W.G. The gender and ethnic diversity of US boards and board committees and firm financial performance. Corp. Gov. Int. Rev. 2010, 18, 396-414. [CrossRef]

47. Williams, R.J. Women on corporate boards of directors and their influence on corporate philanthropy. J. Bus. Ethics 2003, 42, 1-10. [CrossRef]

48. Galbreath, J.; Shum, P. Do customer satisfaction and reputation mediate the CSR-FP link? Evidence from Australia. Aust. J. Manag. 2012, 37, 211-229. [CrossRef]

49. Boulouta, I. Hidden connections: The link between board gender diversity and corporate social performance. J. Bus. Ethics 2013, 113, 185-197. [CrossRef]

50. Hafsi, T.; Turgut, G. Boardroom diversity and its effect on social performance: Conceptualization and empirical evidence. J. Bus. Ethics 2013, 112, 463-479. [CrossRef]

51. Boyd, B.K. CEO duality and firm performance: A contingency model. Strateg. Manag. J. 1995, 16, 301-312. [CrossRef]

52. Carter, D.A.; Simkins, B.J.; Simpson, W.G. Corporate governance, board diversity, and firm value. Financ. Rev. 2003, 38, 33-53. [CrossRef]

53. Ikram, A.; Su, Q.; Fiaz, M.; Shabbir, M.W. Cultural diversity and challenges for female entrepreneurs: Empirical Study of an emerging economy. World Acad. Sci. Eng. Technol. Int. J. Soc. Behav. Educ. Econ. Bus. Ind. Eng. 2016, 10, 3375-3378.

54. Daily, C.M.; Dalton, D.R. Women in the boardroom: A business imperative. J. Bus. Strategy 2003, 24, 5. [CrossRef]

55. Zhang, J.Q.; Zhu, H.; Ding, H.-B. Board composition and corporate social responsibility: An empirical investigation in the post Sarbanes-Oxley era. J. Bus. Ethics 2013, 114, 381-392. [CrossRef]

56. Tinggi, M.A.; bin Md Isa, A.H.; Jakpar, S. A Propitious Approach towards Independent Directors in Malaysian Firms' Board Committee. Int. Bus. Res. 2015, 8, 81. [CrossRef]

57. Leung, T.C.H.; Snell, R.S. Attraction or distraction? Corporate social responsibility in Macao's gambling industry. J. Bus. Ethics 2017, 145, 637-658. [CrossRef]

58. Cheng, E.C.; Courtenay, S.M. Board composition, regulatory regime and voluntary disclosure. Int. J. Account. 2006, 41, 262-289. [CrossRef]

59. Cerbioni, F.; Parbonetti, A. Exploring the effects of corporate governance on intellectual capital disclosure: An analysis of European biotechnology companies. Eur. Account. Rev. 2007, 16, 791-826. [CrossRef]

60. Htay, S.N.N.; Rashid, H.M.A.; Adnan, M.A.; Meera, A.K.M. Impact of corporate governance on social and environmental information disclosure of Malaysian listed banks: Panel data analysis. Asian J. Financ. Account. 2012, 4, 1-24. [CrossRef]

61. Jizi, M.I.; Salama, A.; Dixon, R.; Stratling, R. Corporate governance and corporate social responsibility disclosure: Evidence from the US banking sector. J. Bus. Ethics 2014, 125, 601-615. [CrossRef]

62. Barako, D.G.; Brown, A.M. Corporate social reporting and board representation: Evidence from the Kenyan banking sector. J. Manag. Gov. 2008, 12, 309. [CrossRef]

63. Rashid, A.; De Zoysa, A.; Lodh, S.; Rudkin, K. Board composition and firm performance: Evidence from Bangladesh. Australas. Account. Bus. Financ. J. 2010, 4, 76-95.

64. Akhtaruddin, M.; Hossain, M.A.; Hossain, M.; Yao, L. Corporate governance and voluntary disclosure in corporate annual reports of Malaysian listed firms. J. Appl. Manag. Account. Res. 2009, 7, 1.

65. Chau, G.; Gray, S.J. Family ownership, board independence and voluntary disclosure: Evidence from Hong Kong. J. Int. Account. Audit. Tax. 2010, 19, 93-109. [CrossRef]

66. Eng, L.L.; Mak, Y.T. Corporate governance and voluntary disclosure. J. Account. Public Policy 2003, 22, 325-345. [CrossRef]

67. Gul, F.A.; Leung, S. Board leadership, outside directors' expertise and voluntary corporate disclosures. J. Account. Public Policy 2004, 23, 351-379. [CrossRef] 
68. Ahmad, N.B.J.; Rashid, A.; Gow, J. Board independence and corporate social responsibility (CSR) reporting in Malaysia. Australas. Account. Bus. Financ. J. 2017, 11, 61-85. [CrossRef]

69. Abdullah, S.N.; Mohamed, N.R.; Mokhtar, M.Z. Board independence, ownership and CSR of Malaysian Large Firms. Corp. Own. Control. 2011, 8, 417-431. [CrossRef]

70. Ahmed Haji, A. Corporate social responsibility disclosures over time: Evidence from Malaysia. Manag. Audit. J. 2013, 28, 647-676. [CrossRef]

71. Sartawi, I.I.S.M.; Hindawi, R.M.; Bsoul, R.; Ali, A.J. Board composition, firm characteristics, and voluntary disclosure: The case of Jordanian firms listed on the Amman stock exchange. Int. Bus. Res. 2014, 7, 67. [CrossRef]

72. Adams, R.B.; Hermalin, B.E.; Weisbach, M.S. The role of boards of directors in corporate governance: A conceptual framework and survey. J. Econ. Lit. 2010, 48, 58-107. [CrossRef]

73. Adams, R.B.; Ferreira, D. Women in the boardroom and their impact on governance and performance. J. Financ. Econ. 2009, 94, 291-309. [CrossRef]

74. A Harjoto, M.; Laksmana, I.; Lee, R. Board diversity and corporate social responsibility. J. Bus. Ethics 2015, 132, 641-660. [CrossRef]

75. De Villiers, C.; Naiker, V.; Van Staden, C.J. The effect of board characteristics on firm environmental performance. J. Manag. 2011, 37, 1636-1663. [CrossRef]

76. Marquis, C.; Qian, C. Corporate social responsibility reporting in China: Symbol or substance? Organ. Sci. 2013, 25, 127-148. [CrossRef]

77. Deegan, C.; Soltys, S. Social accounting research: An Australasian perspective. Account. Forum 2007, 31, 73-89. [CrossRef]

78. Brammer, S.; Pavelin, S. Voluntary environmental disclosures by large UK companies. J. Bus. Financ. Account. 2006, 33, 1168-1188. [CrossRef]

79. Cormier, D.; Magnan, M.; Van Velthoven, B. Environmental disclosure quality in large German companies: Economic incentives, public pressures or institutional conditions? Eur. Account. Rev. 2005, 14, 3-39. [CrossRef]

80. Liang, Q.; Xu, P.; Jiraporn, P. Board characteristics and Chinese bank performance. J. Bank. Financ. 2013, 37, 2953-2968. [CrossRef]

81. Doğan, M.; Yildiz, F. The impact of the board of directors' size on the bank's performance: Evidence from Turkey. Eur. J. Bus. Manag. 2013, 5, 130-140.

82. Sahin, K.; Basfirinci, C.S.; Ozsalih, A. The impact of board composition on corporate financial and social responsibility performance: Evidence from public-listed companies in Turkey. Afr. J. Bus. Manag. 2011, 5, 2959.

83. Larcker, D.F.; Richardson, S.A.; Tuna, I. Corporate governance, accounting outcomes, and organizational performance. Account. Rev. 2007, 82, 963-1008. [CrossRef]

84. Rupley, K.H.; Brown, D.; Marshall, R.S. Governance, media and the quality of environmental disclosure. J. Account. Public Policy 2012, 31, 610-640. [CrossRef]

85. Liu, Y.; Miletkov, M.K.; Wei, Z.; Yang, T. Board independence and firm performance in China. J. Corp. Financ. 2015, 30, 223-244. [CrossRef]

86. Brickley, J.A.; Linck, J.S.; Coles, J.L. What happens to CEOs after they retire? New evidence on career concerns, horizon problems, and CEO incentives. J. Financ. Econ. 1999, 52, 341-377. [CrossRef]

87. Ahn, S.; Jiraporn, P.; Kim, Y.S. Multiple directorships and acquirer returns. J. Bank. Financ. 2010, 34, 2011-2026. [CrossRef]

88. Liao, L.; Lin, T.P.; Zhang, Y. Corporate board and corporate social responsibility assurance: Evidence from China. J. Bus. Ethics 2018, 150, 211-225. [CrossRef]

89. Sun, L.; Al Farooque, O. An exploratory analysis of earnings management practices in Australia and New Zealand. Int. J. Account. Inf. Manag. 2018, 26, 81-114. [CrossRef]

90. Reverte, C. Determinants of corporate social responsibility disclosure ratings by Spanish listed firms. J. Bus. Ethics 2009, 88, 351-366. [CrossRef]

91. Branco, M.C.; Rodrigues, L.L. Factors influencing social responsibility disclosure by Portuguese companies. J. Bus. Ethics 2008, 83, 685-701. [CrossRef] 